Academic Platform Journal of Engineering and Science

journal homepage: http://apjes.com/

\title{
Türkiye İçin Bir Taşınmaz Değerleme Sistemi Yaklaşımında UML Tabanlı Veri Modeli Tasarımı
}

\author{
${ }^{* 1}$ Nuri Erdem \\ ${ }^{1}$ Osmaniye Korkut Ata Üniversitesi, Mühendislik Fakültesi, Harita Mühendisliği Bölümü, Osmaniye, Türkiye, \\ nurierdem@osmaniye.edu.tr, \\ Araştırma Makalesi \\ Geliş Tarihi: 22.05 .2018 \\ Kabul Tarihi: 15.03 .2019
}

$\ddot{O} z$

Türkiye taşınmaz değerleme sisteminin yeniden yapılandırılması aşamasında öncelikle doğru, kaliteli ve güncel verilerin kullanıldığı bir veritabanı oluşturulmalıdır. Ancak, bu verilerin gerekli istatistiksel analiz ve modelleme çalışmalarında kullanılabilecek formatta olması gerekir. Bu çalışmada, taşınmaz değerleme faaliyetlerinde kullanılması gereken veriler ve temel özellikleri belirlenmiş ve taşınmaz karakteristikleri veritabanlarının oluşturulması ile ilgili örnek bir UML tabanlı veri modeli tasarımı sunulmuştur. Model tasarımında Enterprise Architect programı ile oluşturulan UML sınıf diyagramları kullanılmıştır. Model ile temsil edilemeyecek durumdaki karmaşık ilişki ve kurallar için ayrıca açıklamalar yapılmıştır. Böylece geliştirilen modelin daha iyi anlaşılması sağlanmıştır. Çalışma kapsamında; arsa, arazi, bina, konut ve işyeri olarak beş ana gruba ayrılan taşınmaz türleriyle ilgili değerleme aşamasında kullanılması gereken verilerin önem derecesi, mevcudiyeti, kaynağı, doğruluğu ve güncelliği gibi özellikleri kullanılarak UML tabanlı bir veri modeli tasarımı gerçekleştirilmiştir. Bu tasarımın temel bileşenlerini; tapu ve kadastro bilgileri, sahadan alınan veriler, imar bilgileri, taşınmaz türü detay bilgileri, çevre ve konum özellikleri, emsal satışlar, bina ve konut özellikleri, ekonomik ve demografik özellikler gibi taşınmaz ve çevresine ait bilgi paketleri oluşturmaktadır. Bu bilgi paketleri içerisindeki sayısal olmayan verilerin standardizasyonu sağlanmalı ve model bir veri-ihtiyaç analizi yapılıyor şeklinde yorumlanmalıdır. Oluşturulan modelin sorunsuz işleyebilmesi için öncelikle taşınmaz değerleme alanındaki mevzuat altyapısı ve kurumsal yapılanmanın da ülkemize uygun bir şekilde oluşturulması gerekmektedir.

Anahtar Kelimeler: Taşınmaz Değerleme, Taşınmaz Değerleme Sistemi, Veri Modeli Tasarımı, UML.

\section{UML-Based Data Model Design in a Real Estate Appraisal System Approach for Turkey}

\author{
${ }^{* 1}$ Nuri Erdem \\ ${ }^{1}$ Osmaniye Korkut Ata University, Faculty of Engineering, Department of Geomatic Engineering, Osmaniye, Turkey, \\ nurierdem@osmaniye.edu.tr
}

\begin{abstract}
In the stage of restructuring of Turkish real estate valuation system, firstly, a database should be created using correct, high quality and up-to-date data. However, these data should be in a format that can be used in the necessary statistical analysis and modeling studies. In this study, data and basic characteristics that should be used in real estate valuation activities have been determined and it has been presented a sample UML-based data model design for the creation of real estate characteristics databases. UML class diagrams created with Enterprise Architect program are used in model design. The complex relations and rules that cannot be represented by the model are also explained. Thus, a better understanding of the developed model has been achieved. Scope of work; a UML-based data model was designed by using the features such as importance, presence, source, accuracy and timeliness of the data that should be used in the appraisal stage related to the real estate types divided into five main groups as land, land, building, residence and workplace. The main components of this design are; information on land and cadastre, data received from the site, development information, real estate type details, environment and location characteristics, precedent sales, building and residential properties, economic and demographic characteristics and information packages. The standardization of non-numeric data in these information packages should be ensured and interpreted as a model data-needs
\end{abstract}


analysis. In order to ensure the smooth functioning of the model, the legislative infrastructure and institutional structuring in the field of real estate appraisal should be established in accordance with our country.

Keywords: Real Estate Appraisal, Real Estate Appraisal System, Data Model Design, UML.

\section{GİRIŞ}

Günümüzde taşınmaz sektörü ve buna bağlı olarak gelişen taşınmaz değerlerinin belirlenmesi hizmetleri, uluslararası küresel ekonomik ilişkilerin vazgeçilmez bir unsuru olmuştur. Değerleme faaliyetleri, ekonomik sistemde bir bütünün içinde geniş bir yer tutmakta ve farklı amaçlarla kullanılmaktadır. Taşınmaz değerlerinin belirlenmesi işi ve bu değerlerin likidite olarak piyasada işlem görebiliyor olması, sağlıklı bir ekonomik yapının en önemli unsurlarıdır [1].

Taşınmaz değerlemeye; vergilendirmeden kamulaştırmaya, özelleştirmeden tescile esas tüm işlemlere kadar yoğun bir şekilde ihtiyaç duyulmaktadır. Gerek bu ihtiyacın karşılanabilmesi gerekse taşınmaz piyasasının (alım-satıma dayalı piyasaların) şeffaflığının sağlanabilmesi için tüm ülkelerin sağlıklı işleyen bir değerleme sistemlerini oluşturması ve sürdürmesi gerekmektedir. Nitekim bugün birçok ülkede, değerleme sistemlerinin tesis edilmesi veya iyileştirilmesi amacıyla hukuki, kurumsal ve teknik çalışmaların yürütüldüğü bilinmektedir [2, 3]. Ülkemizde de bu alanda biran önce dünya standartlarına uyumlu ve sağlıklı işleyen bir sistem oluşturulmasına ihtiyaç duyulmaktadır.

\section{VERİ BILLEŞENLERIYLE ILGILII ARAŞTIRMA YÖNTEMI}

Türkiye taşınmaz değerleme sisteminin yeniden yapılandırılması aşmasında öncelikle doğru, kaliteli ve güncel verilerin kullanıldığ 1 bir veritabanı oluşturulmalıdır. Ancak bu verilerin, gerekli istatistiksel analiz ve modelleme çalışmalarında kullanılabilecek formatta olması gerekir.

Çalışma kapsamında, arsa, arazi, bina, konut ve işyeri olarak beş ana gruba ayrılan taşınmaz türleriyle ilgili değerleme aşamasında kullanılması gereken verilerin önem derecesi, mevcudiyeti, kaynağı, doğruluğu ve güncelliği gibi özelliklerinin sorgulandığı bir anket formu hazırlanmıştır. Her bir taşınmaz türü için ayrı ayrı hazırlanan bu formlardaki değerleme verileri için öncelikle Coğrafi Bilgi Sistemleri Genel Müdürlüğü (CBSGM) tarafından yapılan Türkiye Ulusal Coğrafi Bilgi Sistemleri Standartlarının Belirlenmesi Projesi Veri Teması Uygulama Şemalarında yer alan sınıflardaki veriler esas alınmıştır. Çevre ve Şehircilik Bakanlığı (2012) çalışmasına göre; Türkiye Ulusal Coğrafi Bilgi Sistemi (TUCBS) projesinde oluşturulan veriler, genel olarak taşınmaz karakteristiklerini içeren kadastro ve adres veri sınıfları ile tanımlanmıştır. Ayrıca, adres bilgisi, tapu ve kadastro, ulaşım ve idari birim verileri de çoğunlukla bu proje kaynaklarından elde edilmiştir [4].

Bunun yanında, değerlemede kullanılmak üzere taşınmaz türlerine göre gerekli veriler için en önemli ikinci kaynak,
TKGM'nin toplu taşınmaz değerleme pilot projesinde kullanılmak üzere hazırlanan veri kaynağı tabloları olmuştur. Projede kullanılan tüm veriler tez kapsamında hazırlanmış olan veri tablolarında kullanılmıştır (Ek Tablo 1). Sonrasında, Yomralığlu (1993) tarafindan yapılan ve değere etki eden parametrelerin bilinmesine yönelik doktora tez çalışmasında kullanılan verilerin üzerine [5], Nişancı (2005)'in doktora tez çalışmasında kullandığ 1 veriler eklenmiştir [6]. Ertaş (2014) tarafindan oluşturulan "Kırsal Alanlarda Taşınmaz Değerlemesi" isimli ders notları incelenmiş, kırsal alanlardaki taşınmazların değerini etkileyen veriler ve veri kaynakları gruplandırılmıştır [7]. Düzgün (2010) tarafından oluşturulan ve Ulusal Açık Ders Malzemeleri Konsorsiyumu tarafindan kullanıma sunulan kaynak doküman da incelenmiştir [8]. Ayrıca literatürdeki diğer bilimsel çalışmalarda kullanılan anket formları, birçok değerleme firmasının ve bankaların uzman değerleme raporları incelenmiştir. Farklı değerleme firmalarının çok sayıda rapor örnekleri incelenmiş ve birçok değerleme uzmanından görüş alınmıştır. Bunun yanında konuyla ilgili diğer kaynak kitaplar, makale, bildiri ve yapılmış yüksek lisans/doktora tezleri taranarak ilgili formlardaki veriler geliştirilmiştir. $\mathrm{Bu}$ yolla formlara son şekli verilerek çalışmada kullanılmıştır.

Ancak, taşınmaz çeşitlerinden arazi (tarımsal amaçlı kullanım alanı) değerlemesiyle ilgili Türkiye'de diğer çeşitlere nispeten çok az çalışma vardır. Tanrıvermiş (2000) tarafından yapılan çalışmada; kapitalizasyon faiz oranıyla ilgili temel yaklaşımların ülkemizde uygulanabilirliği araştırılmıştır [9]. Arazi değerleme verileri için hazırlanan tablolardaki bilgiler, Aliefendioğlu (2011) tarafindan yapılan doktora çalışması sonuçları ve bu çalışmada kullanılan arazi formlarından elde edilmiştir [8].

Anket çalışması sırasında sorularının yanıtlanması için yüz yüze görüşmelerin daha uygun olabileceği düşünülmüş, başta Osmaniye, Adana, Mersin, Kahramanmaraş, Hatay, Kayseri ve İzmir olmak üzere ülkemizin birçok şehirlerinde görüşmeler yapılmış ve anket formları doldurulmuştur. $\mathrm{Bu}$ sırada özellikle kamu kurumlarında çalışanlar için kamulaştırma bilirkişi sertifikası olan harita mühendisi, şehir plancısı, inşaat mühendisi, iktisatçı ve işletmeci gibi meslek gruplarından kişiler olması esas alınmıştır. SPK lisanslı değerleme şirketlerinde çalışanlar için genel müdür, yönetim kurulu üyesi veya gayrimenkul değerleme uzmanı olmaları istenmiştir. Ayrıca çözüm ortağı olarak çalışan teknik elemanlarla da anketler yapılmıştır.

Yüz yüze görüşme yapma imkânının olmadığı anketörler için elektronik posta yolu tercih edilmiştir. Uzun yıllar bu alanda çalışmaları olan 9 değerleme uzmanıyla her biri yaklaşık 2-3 saat süren yüz yüze görüşmeler yapılmıştır. Görüşmeler sırasında daha sonra çözümlemede yardımcı olması amacıyla ses kayıtları da alınmıştır. Karşılıklı 
görüşme imkânı bulunamayan diğer 21 uzmandan e-posta ortamında bilgi temini sağlanmıştır. $\mathrm{Bu}$ kapsamda görüşmelerde; taşınmazların türüne göre (arsa, arazi, bina, konut ve işyeri) değerleme verileri, kalitesi, mevcudiyeti ve bileşenlerin uygunluğu yanında, önem derecesi konusunda uzmanların ayrı ayrı düşünceleri sorulmuş ve görüşler bir araya getirerek bir orta yol bulunmuştur. Ayrıca, eğer Türkiye için yeni bir taşınmaz değerleme modeli oluşturulmak istenirse, bu yeni sistemde değerleme verilerinin üretim ve güncellemesinden hangi kurum sorumlu olmalıdır gibi sorulara da cevap aranmıştır. Uzmanların görüş ve önerileri doğrultusunda formlardaki veriler ve özellikleri hakkında düzenlemeler (ekleme/çıkarma) yapılmış ve oluşturulan formların son şekli Ek Tablo 1'de verilmiştir.

\section{UML TABANLI VERI MODELİ TASARIMI}

"Unified Modeling Language" İngilizce ifadenin kısaltmış şekli olan UML, nesne yönelimli tasarım çalışmaları için yaygın bir şekilde kullanılmaktadır [10, 11]. Günümüzde UML, birçok alandaki iş akış süreçleri için kullanılan bir modelleme dilidir $[11,12]$.

Öncelikle değerlemede kullanılması gereken veriler ve temel özellikleri belirlenmiştir. Bu bağlamda hem tekil hem de toplu değerlemeye de altlık oluşturabilecek verilerin kullanımı için bir UML tabanlı veri modeli geliştirilmiştir. Model tasarımında Enterprise Architect (Versiyon 7.5) programı ile oluşturulan UML sınıf diyagramları kullanılmıştır. Modelin daha iyi anlaşılabilmesi için ayrıca açıklamalar yapılmıştır. Modelin uygulanması aşamasında karşılaşılabilecek problemler için bazı alınması gereken önlemler de sunulmuştur.

Çalışmada; arsa, arazi, bina, konut ve işyeri olarak beş ana gruba ayrılmış olan taşınmazlar için değerlemede gerekli olan veriler, veri kaynakları, verilerin kalitesi, güncelliği ve önem derecesi gibi değerleme verilerinin temel özelliklerinin belirlenmesinde yüz yüze anket çalışması gerçekleştirilmiştir. Bu çalışma, büyük ölçüde değerleme faaliyeti yürüten kamu kurumlarının İ ve Genel Müdürlüklerinde görevli uzman ve yöneticileri ile özel sektör değerleme uzmanlarıyla yapılmıştır. Aynı zamanda, ülkemizde değerleme faaliyetlerinin altyapısının güçlendirilmesi için yürütülen kamu (TKMP taşınmaz değerleme bileşeni) ve özel sektör çalışmalarından da yararlanılmıştır.

Önemli görülen tüm veriler, ortak özelliklere sahip nesnelerin temsil edildiği sınıflar içerisindeki öznitelik verileri olarak kullanılmıştır [13]. Sahadan Alınan Veriler, Ekonomik ve Demografik Özellikler, Tapu Kadastro Bilgileri, İmar Bilgileri, Emsal Satışlar, Taşınmaz Türleri, Çevre ve Konum Özellikleri gibi diğer veri sınıflarında görsellik ve daha iyi anlaşılabilmesi açısından farklı renkler kullanılmıştır. Ayrıca, hem tekil ve hem de toplu değerleme çalışmalarında gerçek veya tüzel kişilerin izlenmesi gereken işlem adımları için Taşınmaz Değerlemesi paketi oluşturulmuştur. Şekil 1'de görüldüğü üzere Sahadan Alınan Veriler için bu paket içerisinde RayiçDeğeri sınıfı oluşturularak, bu sınıf içerisinde bulunan emsal alım-satım değerleri için EmsalSatışlar paketi tasarlanmıştır. Bu şekilde paketler arasındaki yoğun ilişkileri tanımlamak amacıyla <<use>> ilişkisinin kurulması gerekmiştir.

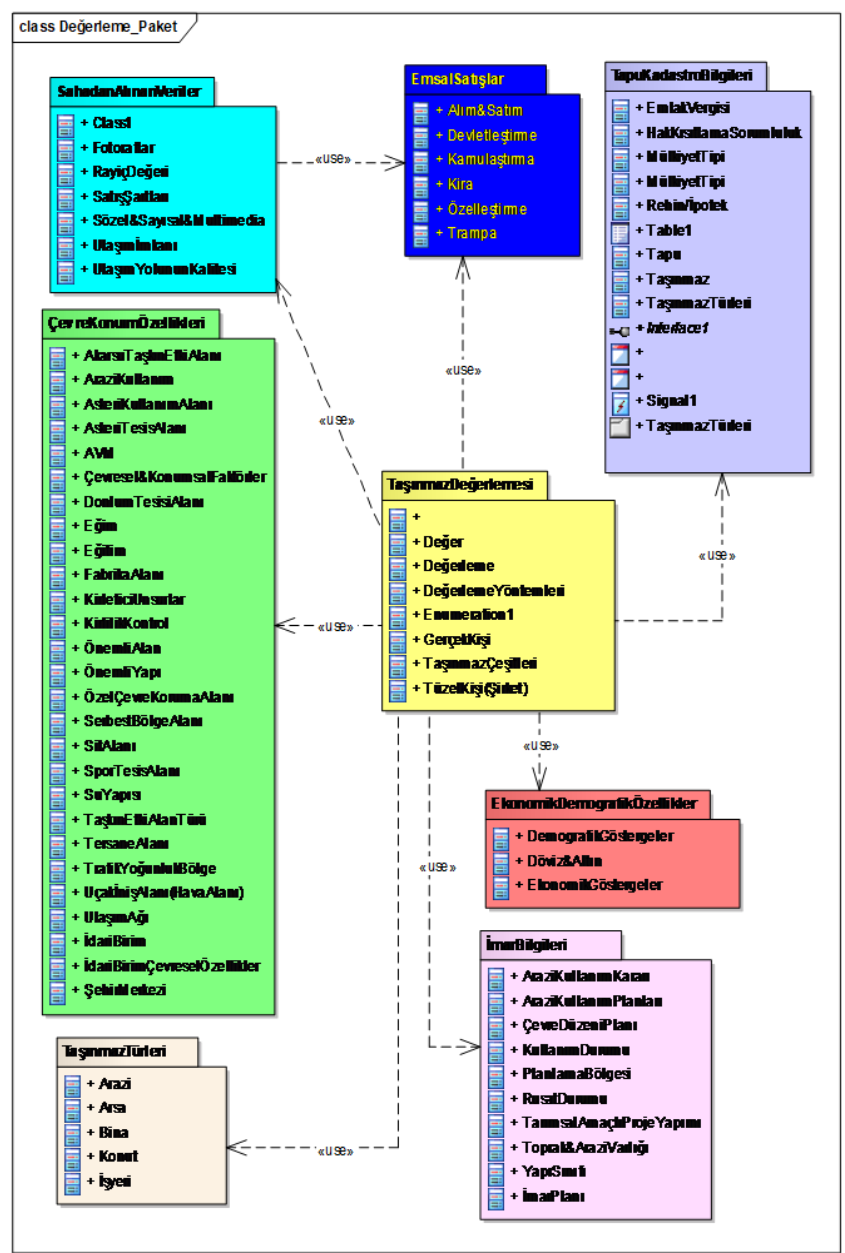

Şekil 1. Model için oluşturan veri setlerinin genel görünümü ve aralarındaki ilişkiler ([13]'den geliştirilmiştir.)

Association (ilişkili olma), nesneler arasında bazı anlamsal bağlılıkları ifade eden fiziksel ve kavramsal bir ilişki olduğu için, çalışma kapsamında bir nesnenin kendi içerisinde bulunduğu sınıfın veya bir başka sınıfın temsil ettiği hangi nesnelerle ilgisi olduğunu tanımlamak için kullanılmıştır. Generalisation (genelleme), farklı nesneleri temsil eden sınıfların ortak özellikli diğer sınıflarla gruplama suretiyle temsil edilmesi ilişkisine dayandığı için, aynı türde daha genel nesnelerin temsil edilmesinde tercih edilmiştir [11]. Tam tersi olarak, specialisation (özelleme) ise birbirinin tersi ilişkiler olup aynı türde daha özel nesnelerin temsil edilmesinde kullanılmıştır.

DeğerlemeYöntemleri sınıfında, kullanılabilecek değerleme yöntemleri için (geleneksel, modern, istatistiki vb.) tanım kümeleri oluşturulmuştur (Şekil 2). DeğerlemeTürü sınıfinda yer alan tekil veya toplu değerleme türlerinden 
birisi seçilerek taşınmaz değerlemesinin yapılması öngörülmüştür.

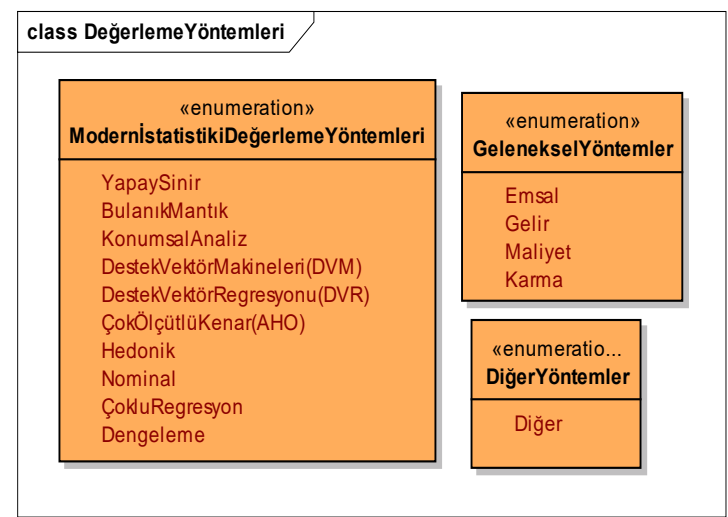

Şekil 2. Değerleme yöntemleri tanım kümeleri.

\subsection{Taşınmaz Değerlemesi Paketi}

Taşınmaz Değerlemesi Paketi, içerisinde bir kuruluş (kamu/özel sektör) tarafindan yapılan bir toplu değerleme işlemine ilişkin bilgileri temsil etmek amaciyla tasarlanmıştır. $\mathrm{Bu}$ bilgilerin hangi sınıflarda tutulması gerektiği önemlidir. Uzman bir değerlemeci bilgileri DeğerlemeRaporu sınıfı içerisinde yer almıştır. Kamu veya özel sektör kuruluş bilgileri de GerçekKişi ve TüzelKişi (Şirket) sınıflarında detaylandırılmıştır. Çalıșma kapsamında ister tekil isterse toplu değerleme işlemi olsun, bir değerleme işleminin yalnızca bir müşteri kişi veya kurum (özel veya tüzel kişi) tarafindan talep edilebileceği gerçeğinden hareketle taşınmaza ait Değer sınıfında $<<1 .{ }^{*}>>$ çokluk ifadesi kullanılmıştır. Aynı şekilde farklı zamanlarda aynı müşterilerin aynı veya paket içerisinde $<<$ enumeration $>>$ olarak tanımlanan farklı taşınmazlar için değerleme talep edebileceği düşünülerek iki sınıf arasındaki ilişkinin çokluk ifadeleri $<<1 .{ }^{*}>>$ şeklinde belirlenmiştir. Paket içerisinde, IstatistikiYöntemler ve ModernDeğerlemeYöntemleri gibi tanım kümeleri oluşturulmuştur (Şekil 3).

Toplu değerleme işlemi esnasında, birden fazla taşınmaz için değerleme işlemi yapılabileceği dikkate alınarak üretilen değerlerin Değer sınıfi ile temsil edilmesi öngörülmüştür. TaşınmazTürleri sınıfınca temsil edilen taşınmazlar (arazi, arsa, bina, konut, işyeri) için farklı zamanlarda veya farklı yöntemlerle (geleneksel, modern, istatistiki vb.) değerler belirlenebileceği gerçeğinden hareket ederek sınıf içi nesne ilişkileri aynı sınıf üzerindeki ilişki ile tanımlanmıştır (Şekil 3). Ancak, aynı taşınmazın zaman içerisinde değerinde bazı değişimler oluşabilecektir. $\mathrm{Bu}$ değişimlere göre ilgili taşınmazın toplu değerleme yöntemi ile üretilen değerinde doğrudan değişiklik yapılabilmesi için, değeri etkileyebilecek faktör analizlerinden sonra, sınıf içi nesne ilişkileri aynı sınıf üzerindeki Zamansal bağıntı ilişkisi ile gösterilmiştir.

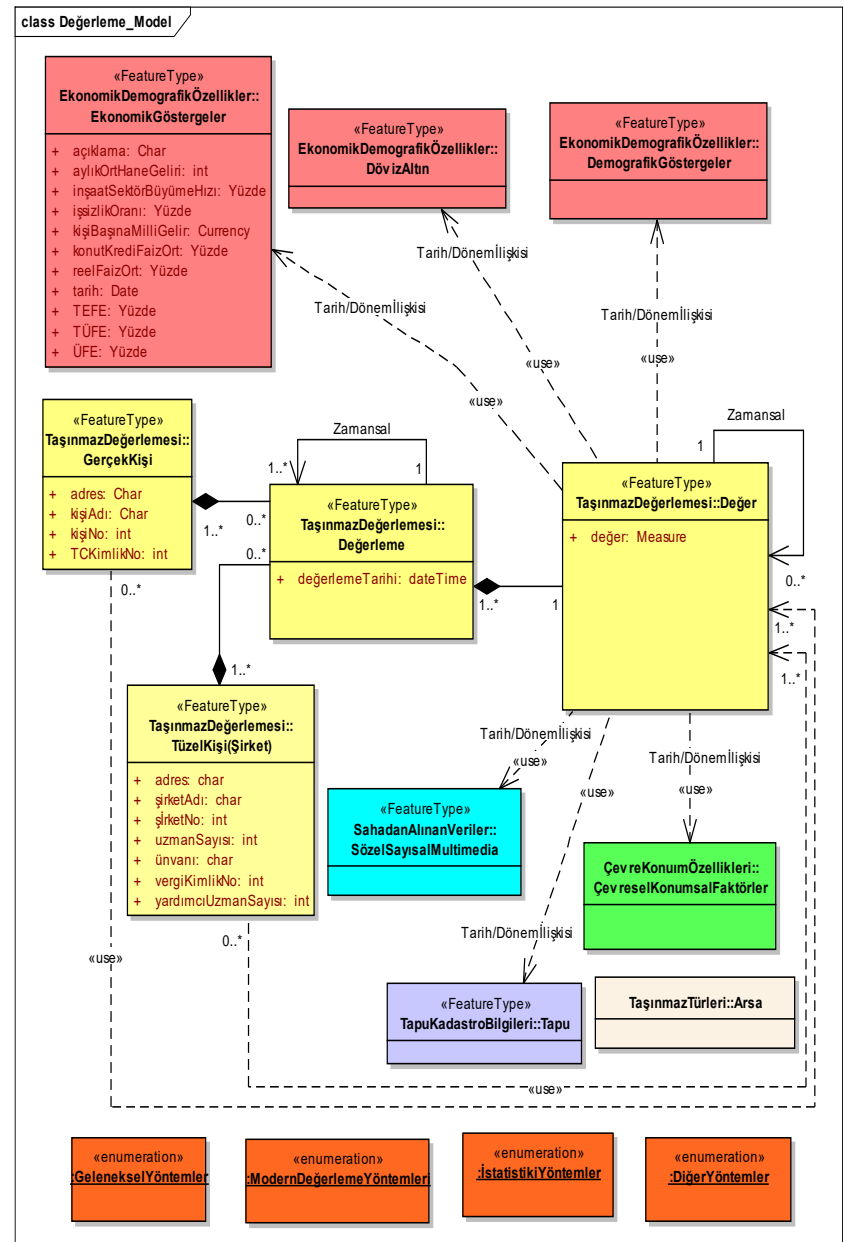

Şekil 3. Taşınmaz değerlemesi paketi içeriği.

\subsection{Tapu ve Kadastro Bilgileri Paketi}

Tüm taşınmaz çeşitlerinin (arazi, arsa, bina, konut ve işyeri) en temel özelliği olan üzerinde bulunduğu imar veya kadastro parseli ile ilgili konum ve mülkiyet bilgilerine ihtiyaç vardır. $\mathrm{Bu}$ nedenle TapuKadastroBilgileri paketi içerisinde Parsel ismiyle ayrıca ve genel bir sınıf oluşturulması gereği doğmuştur. İlgili sınıfın öznitelik bilgilerinde, kadastro veya tapu kayıtlarında yer alan idari sınırlara ilişkin nitelikler ve ayrıca ada ve parsel numaralarına ilişkin nitelikler de tanımlanmıştır.

\section{3. İmar Bilgileri Paketi}

Değerlemede kullanılması gereken verilerden olan ve sınıflarla temsil edilen planlama bölgeleri, imar planı ve çevre düzeni planı öznitelikleri değerleme işlemlerinde parsel (arsa) nitelikleri olarak dikkate alınmaktadır. Bunun gerçekleşmesi için parselin konumuna rastlayan özelliklerin parselle ilişkilendirilmesi gerektiğinden ve bunun konumsal analiz sonucu elde edileceğinden modelde $<<$ use $>>$ ilişkisi kullanılmıştır. Çeşitli teknik şartlar göz önüne alınarak yapılan planlama işlemleri;

- Mücavir alan sınırlarında, 
- Belediye sınırlarında,

- Planlı saha dişında mevzii bir bölgede veya plansız bölgede olabilir.

$\mathrm{Bu}$ durumu ifade edebilmek için PlanlamaBölgesi sınıfı tasarlanmıştır. $\mathrm{Bu}$ planlama bölgelerini tanımlamak amaciyla;

- $\mathrm{Bu}$ sınıfin türü niteliğinin veri tipi olarak PlanlamaBölgesiTürü tanım kümesi,

- İnşaat ruhsatı ve yapı kullanım izin belgesinin varlığının sorgulanabileceği RuhsatDurumu tanım kümesi,

- Planın hangi aşamada olduğunu belirlemek amaciyla da durumu niteliğinin veri tipi olarak PlanDurumu tanım kümesi,

- İmar planlarındaki gösterim ile aktif kullanım arasında olabilecek farklılıkların gösterimi amacıyla KullanımDurumu tanım kümesi,

- Diğer öznitelikleri olan planlamanın hangi kanun hükümlerine (tip veya özel imar kanunu) tabi olduğunu KanunKapsamı tanım kümesi, tasarlanmıştır.

İmar planlarında gösterilebilecek tüm hak ve kısıtlamalar (TAKS, KAKS, hMax, önBahçe, vb.) ImarPlanı sınıfında belirtilmiştir. Kullanılmayan imar hakkı (5 kata imarlı bir alanda henüz yapılmamış 2 kat daha) varsa, bu hakkın miktarı saha ve imar durumuyla birlikte değerlendirilmelidir. Planda öngörülen kullanım türleri için kullanım özniteliğinin veri tipi olarak PlanlananKullanım tanım kümesi oluşturulmuştur. Ayrıca ilgili sınıfta yapı düzenleri de düzen niteliğinin veri tipi olarak YapıDüzeni tanım kümesi ile tanımlanmıştır. İmar Kanunu ve ilgili yönetmelik hükümlerine göre en temel imar koşullarını temsil eden minBinaCephesi ve minBinaDerinliği nitelikleri PlanlamaBölgesi sınıfında temsil etmektedir. Bunlar veri ile ilgili olmayıp yönetmelikle ilgili olmasına rağmen, değerlemede parselin boyutlarına bağlı olarak inşaat alanını belirten veriler olduğu için önemli olabilir.

\subsection{Sahadan Alınan Veriler Paketi}

Taşınmaz değerlemedeki veri kaynağı hususunda yaşanan problemlerin başında tapu müdürlüklerindeki devir işlemleri sırasında doğru beyanda bulunulmaması ve "değer" bilgilerinin ortak bir veritabanı içerisinde tutulamaması gelmektedir [14]. Toplu değerleme sırasında örneklem amacıyla uygulama alanlarında seçilen taşınmaz karakteristiklerine ait veriler ile emsal satış bilgileri, emlakçılardan, Tapu Müdürlüğü, TAKBİS ve Belediyelerden temin edilmelidir. $\mathrm{Bu}$ nedenle değerleme çalışmalarının en önemli aşamalarında birisi olan verilerin toplandığı saha çalışmaları için Sahadan Alınan Veriler Paketi oluşturulmuştur (Şekil 4).

Toplu değerlemede kullanılmak üzere taşınmazların bulunduğu bölgenin gelişmişlik durumunun belirlenmesi gerekir. Bunun için sahada emlakçılar, yerel esnaf vb. ile yapılan görüşmeler neticesinde, örneklem olarak seçilen taşınmazların bulunduğu çevredeki diğer mahalle, sokak, cadde vb. ile karşılaştırmalar yapılarak bilgiler toplanmalıdır. Yapılacak değerlendirmelerde, imar planındaki duruma göre yerleşmenin tamamlanıp tamamlanmadığı hususları da göz önünde bulundurulmalıdır. $\mathrm{Bu}$ bağlamda derecelendirme Çok Gelişmiş, Gelişmiş, Az Gelişmiş ve Gelişmemiş şeklinde olabilir. Örneklem olarak seçilen taşınmazların emlak beyan değeri Belediye emlak servisinden alınarak taşınmaz değerleme raporunda yazılacaktır.

Toplu değerlemede örneklem grubu taşınmazlara ait olmak üzere hesaplama yapacak uzman tarafindan, değişkenlere (değere etki eden faktörlere) ilişkin verilerin toplandığı her taşınmaz için kira bedeli ve tahmini satış değerlerini de araştırılmalıdır [14]. Bu verilerin kontrolleri sahada yapılan emlakçı ziyaretleri ve fiyat araştırmalarının karşılaştırması ile gerçekleştirilebilir (Şekil 4). Emlakçıların yaptıkları satışları ABD'dekine benzer bir şekilde, taşınmaza ait satış geçmişi ve verilen teklifler de görülebileceği, değerlemede kullanılan taşınmaz karakteristikleri veritabanı ve emsal satışlar verilerini girebilecekleri bir sistem oluşturmalı, ancak sistemin kontrolü mutlaka önerilen lider kurum TDGM (Taşınmaz Değerleme Genel Müdürlüğü)'de olmalıdır. İstenen kira veya istenen satış fiyatı tespiti için konu taşınmazlardan, kiralık ya da satılık ilanı bulunan taşınmazlarda, ilanın fotoğrafı mutlaka çekilmeli, müşteri gibi davranarak telefonla aramak ya da yüz yüze görüşme yapmak gibi veriye ulaştırabilecek tüm seçenekler denenmelidir. Toplu değerleme için bu verilerin önceden toplanması gerektiğinden, TAKBİS nitelik bilgilerinin yanında, örneklem grubundaki her taşınmaza ait veriler, sahadan alınan bilgilerle netleştirilmelidir. Taşınmazların mevcut kullanımın (otopark, konut, işyeri vb.) belirlenemediği durumlarda, yasal kullanım amacı ne ise o nitelik değerlemede esas alınmalıdır [14]. Kullanım amacının farklı olduğunun tespiti durumunda, mevcut kullanım amacı belirtilmelidir. Her iki kullanım amacı için gereken bütün bilgiler sahadan alınmalıdır.

Toplu değerleme yapılacak alandaki cadde veya sokak genişliği, kaldırım dâhil olmak üzere metre cinsinden hâlihazır durum haritasından alınabilir veya gerekiyorsa sahadan ölçülebilir. Fazla yapılaşma varsa, bu durum, saha ve imar durumu birlikte değerlendirilmelidir. Resmi kayıtlara göre veya sahadaki kontroller sırasında taşınmazlar üzerinde otopark olduğu tespit edilmişse, otoparkın özelliği de (açık/kapalı) dikkate alınmalıdır [14].

Ülkemiz genelinde tarım işletmelerinde herhangi bir kayıt tutulmamaktadir. $\mathrm{Bu}$ nedenle tarım arazilerinin değerlemesinde de sahadan alınan veriler önemli bir yer tutmaktadır. Bu tür taşınmazların güncel bilgilerinin elde edilmesinde, arazi malikleriyle yüz yüze görüşmeler veya anket çalışmaları uygulanmaktadır. Ayrıca, ilgili kurum ve kuruluşlardan gerekli veriler toplanmalıdır [15]. 


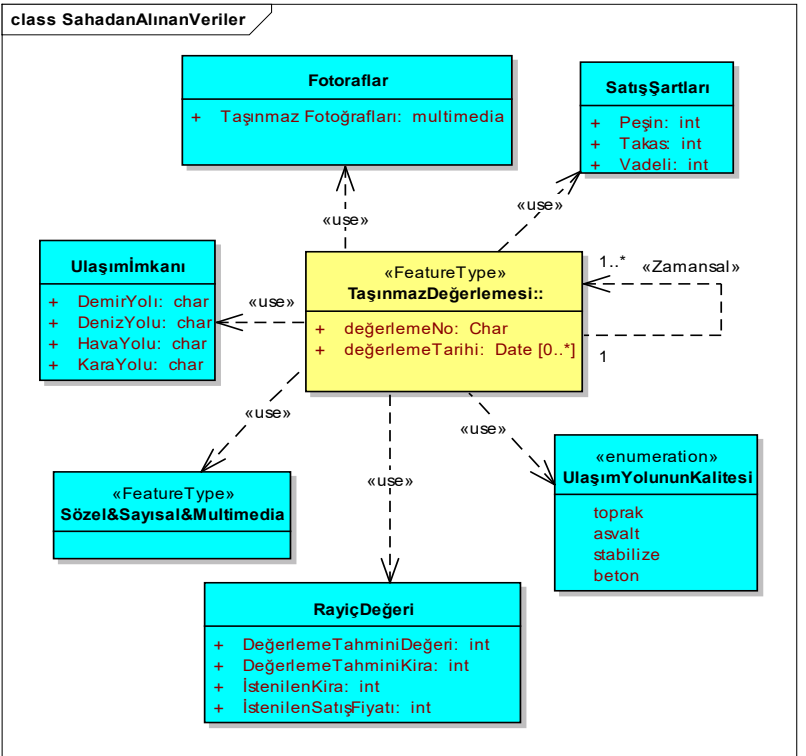

Şekil 4. Sahadan alınan veriler paketi içeriği.

\subsection{Cevre ve Konum Özellikleri Paketi}

Taşınmazların bulunduğu çevre ve konum özellikleri önemli değerleme verilerindendir. Örneğin, bölgenin gelişme trendi, taşınmazın hem günümüzdeki ve hem de gelecekteki fiyatını etkiler. Taşınmaz değerlerini etkileyebilecek çok sayıda çevresel ve konumsal veriler mevcuttur. $\mathrm{Bu}$ bağlamda çalışma kapsamında, kamu ve özel sektör değerleme uzmanlarıyla yapılan mülakatlar haricinde, her taşınmaz türü için ayrı ayrı oluşturulan ve ekler bölümünde (Ek 1) verilen değere etki eden veriler, veri kalitesi, kaynağı ve güncelliği ile ilgili bir anket çalışması da yapılmıştır. Bu çalışmayla ilgili detaylı bilgiler önceki bölümlerde verilmiştir. Anket sonuçlarına göre model geliştirilmiştir. Taşınmaz değerlerini etkileyebilecek çok sayıda çevresel ve konumsal verilerin olması, bu verilerin sahadan toplanması zorunluluğu gibi sıkıntılar resmi kurum ve özel sektördeki anket ve mülakatlar sırasında sıkça dile getirilmiştir.

Genel olarak, bu alandaki verilerde sınırlama ve gruplama yapılması gereği üzerinde durulmuştur. Böyle bir veri yoğunluğundan dolayı bu paket içeriğindeki sınıfların öznitelikleri gösterilmeden özet olarak sunulmuştur. Sınıfların nitelikleri ve veri tipi tanım kümeleri ise detaylı olarak gösterilmiştir. Buradaki düşünce, gerekli verilerin sahadan toplamaktan ziyade bunların doğrudan veriyi üreten kurumlardan alınabileceği veya çevrimiçi erişilebileceği, aynı zamanda CBS ortamında coğrafi analizlerle hesaplamalara tabi tutulabileceği sistem yapılanmasıdır. Taşınmazların çevresel ve konumsal faktörler ile ilişkilerinin sağlanması, imar bilgilerinde olduğu gibi ancak konumsal analizlerle gerçekleşebilecektir. $\mathrm{Bu}$ nedenle bütün faktör sınıflarıyla taşınmaz sınıfı arasında $<<$ use $>>$ ilişkileri kullanılmıştır.
Çevre ve Konum Özellikleri Paketi içerisinde ŞehirMerkeziTürü, TaşkınEtkiAlanTürü, ve KirleticiUnsurlar gibi tanım kümeleri tasarlanmış ve bu kümelerle ilgili olabileceği düşünülen öznitelikler tanımlanmıştır. Değerleme için gerekli olan uzaklık bilgileri web tabanlı haritalama sistemleri, kent bilgi sistemi veya CAD programları kullanılarak metre cinsinden hesaplanabilir. Mesafeler en kısa yürüme yolu olarak hesaplanmalı, kuş uçuşu mesafeler dikkate alınmamalıdır.

\subsection{Bina ve Konut Değerlemesi Paketi}

OzetYapi ve OzetBina detay tiplerinin TKMP taşınmaz değerleme pilot proje çalışmasında kullanılan bina detay verileriyle de birçok benzerlikler gösteren özniteliklere sahiptir (Şekil 5). ÇŞB (2012) çalışmasında TUCBS için tasarlanan ve TKMP taşınmaz değerleme pilot proje çalışmasında da kullanılmış olan Bina veri sınıfında tanımlanan ve bina/konut değerlemesinde kullanılması gereken veri tipleri ve bunların ilişkileri gösterilmiştir (Şekil $5)$.

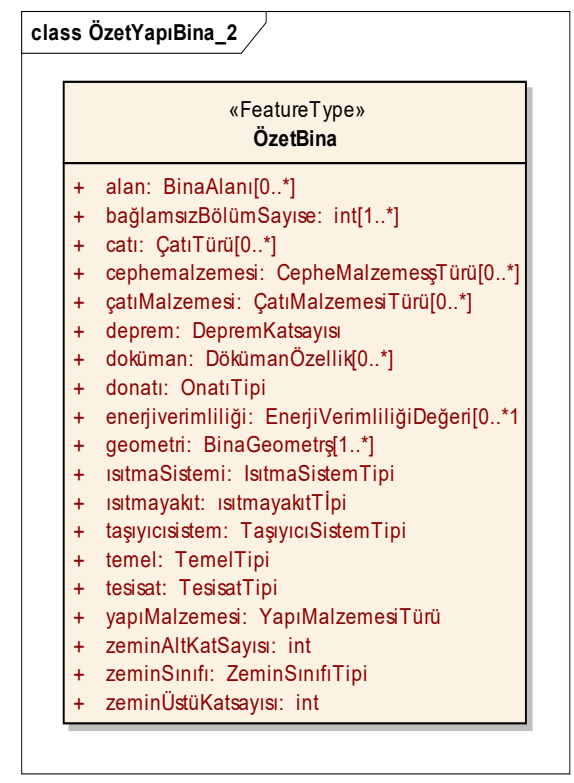

(a)

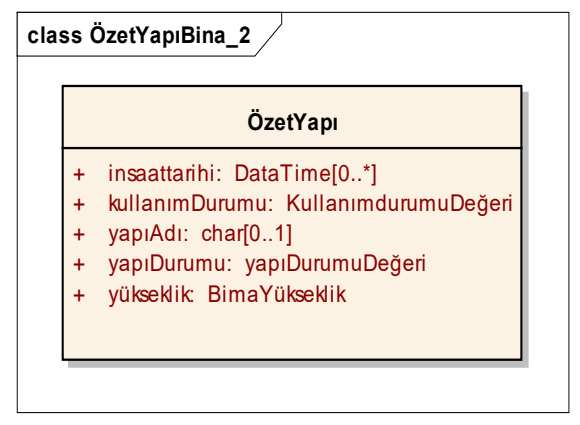

(b)

Şekil 5. Bina detay tipleri [4]. 


\section{Bina değerlemesi için;}

1- Değerleme işleminde yalnızca binanın değeri hesaplanmak isteniyor ve "Maliyet Yöntemi" tercih ediliyorsa, Çevre ve Şehircilik Bakanlığının (ÇŞB) her yıl yayınlamış olduğu yapı yaklaşık birim maliyetleri tablosu kullanılmak suretiyle değerlemesi yapılır. Ancak değerleme işlemi üzerinde bulunduğu arsayı da kapsıyor ise, arsa değeri buna ilave edilerek "yapılı arsanın değeri”" hesaplanmış olur.

2- Eğer yapılı arsa değerlemesinde, "Maliyet Yöntemi" dışındaki değerleme yaklaşımlarından birisi kullanılmak isteniyorsa, veri tekrarı olmaması açısından, arsa değerlemesi için oluşturulan veri tablosuna ilave olarak bina veri tablosunu kullanmak suretiyle "yapılı arsanın değeri" hesaplanmış olur.

Toplu değerleme işleminde Bağımsız bölümlerin bakış yönü, mimari proje ve kadastral pafta, hâlihazır harita, uydu görüntüsü çakıştırılarak tespit edilmelidir. Bağımsız bölümün yoğun olarak baktığı cephe belirlenmelidir. Bağımsız bölümün baktığı yönlerin sayısı mimari proje ve kadastral pafta, hâlihazır harita, uydu görüntüsü çakıştırılarak sağlanmalıdır.

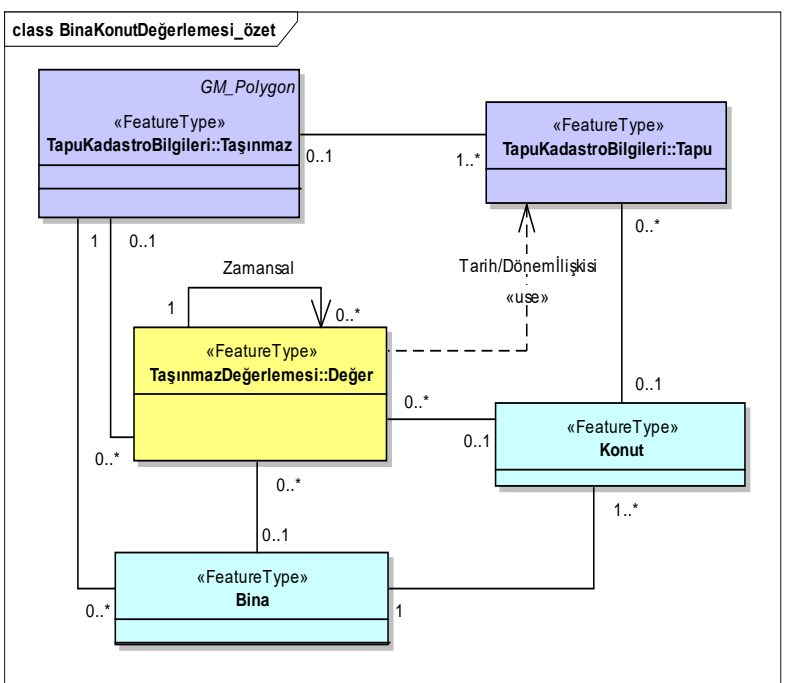

Şekil 6. Bina ve konut özellikleri paketi içeriği özeti.

Bina sınıfının yordam kısmında, bina yaşı, net/bürüt alan katsayısı, inşaat maliyeti, vb. sayısal nitelikler tanımlanmıştır. Bunun yanında sayısal olmayan (spor alanı, yüzme havuzu, güvenlik, vb.) birçok niteliğin veri tipinin de tanımlanması gerekmektedir. Bina sınıfına benzer şekilde Konut sınıfında da konutlara özgü nitelikler ve yordamlar tanımlanmıştır (Şekil 6). Hesaplanabilecek olan faktörler uzman marifetine bırakılmadan hesaplanması için bu yordamlar oluşturulmuştur. Burada amaç, minimum uzman marifeti, maksimum otomasyon olacak şekilde bir modelleme yaklaşımı ortaya koymaktır. BinaKonutDeğerlemesi veri paketindeki Bina ve Konut sınıflarının diğer paketlerdeki sınıflarla (Değerleme: Değer,
TapuKadastroBilgileri: Tapu, TaşınmazTürüDetayBilgileri: Arsa ve TapuKadastroBilgileri: Taşınmaz) olan ilişkileri de tanımlanmıştır. Bunun yanında bu pakette yapılan işlemlerin daha kolay anlaşılabilmesi için, paket içeriği özeti ayrıca oluşturulmuştur (Şekil 6).

\subsection{Ekonomik ve Demografik Özellikler Paketi}

EkonomikDemografikÖzellikler veri paketindeki değerleme işlemini tüm taşınmazlar için ve özellikle toplu değerleme açısından daha geniş bir bakış açısıyla incelemek gerekir. Çünkü toplu taşınmaz değerleme işlemlerinde tekrarlı (yıllık veya iki-üç yılda bir) değerlemeler söz konusu olacağından dolayı tasarlanan modelin bu yapıya uygun olması gerektiği düşünülmüştür. Örneğin; elimizde emsal taşınmazla ilgili eski tarihli bir değerleme işlemi sonucu hesaplanmış bir fiyat varsa ve bunun günümüze uyarlanması gerekiyorsa TEFE, TÜFE veya ÜFE gibi ekonomik göstergelerin yanında döviz/altın gibi yatırım araçlarının ve diğer demografik göstergelerin de dikkate alınması gerekir. Dolayısıyla toplu değerleme tarihindeki değeri hesaplayabilmek için ekonomik göstergelerin tümü göz önünde bulundurulmalıdır. Paket içerisindeki sınıfların nitelikleri de buna uygun tanımlanmıştır. Yeni bir değerleme işlemi yapılmadığından, eğer varsa o taşınmazla ilgili olan diğer hususlarla birlikte, eski ekonomik göstergelerle yeni ekonomik göstergelerin karşılaştırarak (eski değeri kullanarak yeni bir değer üretmek için ekonomik göstergelere göre güncellenmiş) yeni bir değer elde edebilmek için bu veri paketi diyagramı tasarlanmıştır.

$\mathrm{Bu}$ model sayesinde taşınmazların bugünkü toplu değerini hesaplarken güncel ekonomik göstergeler kullanılmalıdır. Eğer gerekiyorsa bundan on yıl sonrasında (taşınmazda veya çevresinde değere etki edebilecek önemli bir değişiklik olmamak şartıyla) özellikle vergisel amaçlı toplu değerlemelerde o günkü göstergelere göre yeni bir değer üretilebilecektir. Ayrıca değerleme yapılırken birçok emsal değer kullanılmış olabilir. Örneğin değerleme işlemleri 2010, 2012 veya daha eski tarihli değerleme yapılmış ise, bunların günümüze indirgemesi ancak bu diyagram yardımıyla mümkündür. Toplu değerleme işlemlerinde herhangi bir dönüşüm yapılmak zorunda kalınmaması için özellikle yakın dönemdeki değerleme sonuçları alınmalıdır.

\subsection{Arsa - Arazi Değerlemesi Paketi}

Diğer taşınmaz türlerinden farklı olarak özellikle boş arsa (yapısız) ve arazi (tarımsal alan) değerlemesinde kullanılmak üzere Arsa-Arazi Değerlemesi Paketi tasarlanmıştır. Paket içeriğindeki özellikle arazi değerlemesi sırasında toplu değerlemenin yanı sıra tekil değerlemenin de uygulanmak istenebileceği düşüncesiyle, değerleme türü olarak TekilDeğerleme tanım kümesi de oluşturulmuştur (Şekil 7).

Değerleme konusu arsaların üzerinde herhangi bir yapılaşma veya eklenti yoksa boş arsa olarak işlem görür. Eğer üzerinde inşaat yapılanmaları varsa, yapı ayrı arsanın ayrı değerlemesi 
yapılması gerekir. Eğer değerleme işleminde maliyet yaklaşımı (modelde GelenekselYöntemler isimli tanım kümesi içerisinde belirtilmiş olan değerleme yöntemi) kullanılacaksa, bu işlemin bir parçası olarak amortismanlı bina değeri, arsa değerine eklenmelidir.

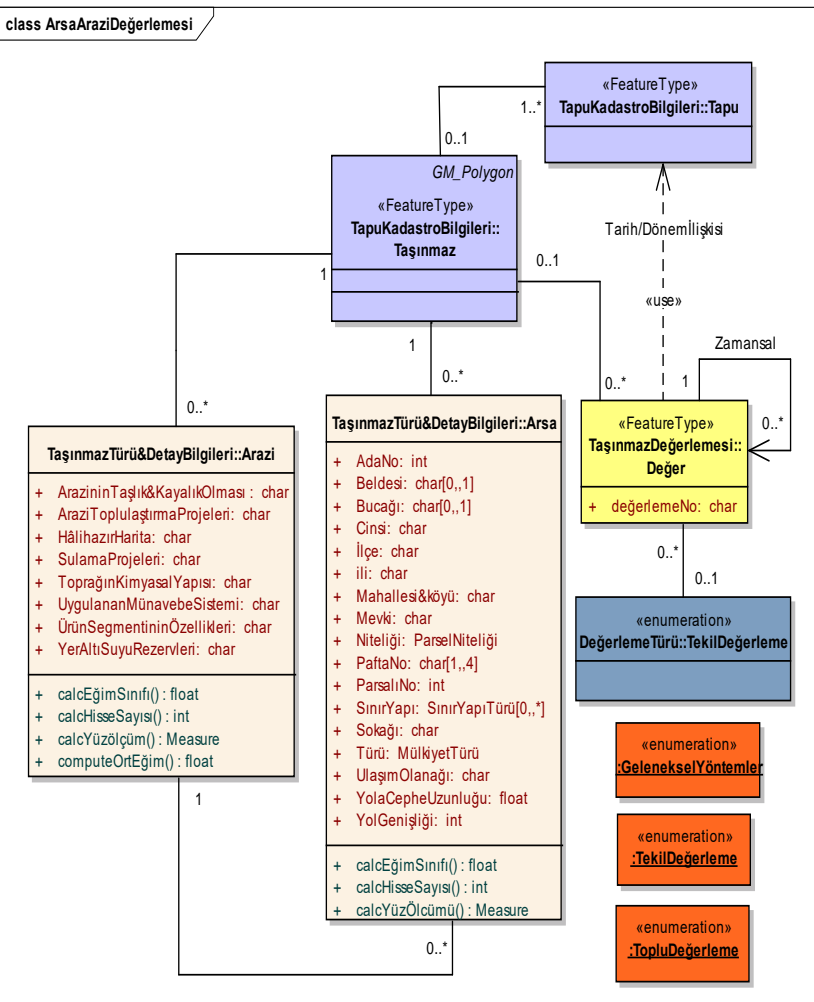

Şekil 7. Arsa - arazi değerlemesi paketi içeriği.

\section{9. İşyeri Değerlemesi Paketi}

İşyeri Değerlemesi Paketi içeriği oluşturulurken BinaKonutDeğerlemesi::Bina sınıfı kullanılmıştır. Çünkü binanın bir parçası olan ve işyeri olarak kullanılan birçok birim bağımsız bölüm olarak binalar içerisinde (İşhanları, AVM, Ofis Blokları, İş Merkezleri, vb.) bulunmaktadır. Dolayısıyla her bir işyeri BinaKonutDeğerlemesi::Bina sınıfı ile doğrudan veya dolaylı olarak ilişki içerisinde olacaktır. İşyerinin değerlemede kullanılacak temel niteliklerini ve ilişkilerini tanımlamak için iki (Bina ve İşyeri isimli) sınıf tasarlanmıştır. Bir binada birden fazla işyeri (bağımsız bölüm) olabileceği gerçeğinden hareketle iki sınıf arasındaki ve ilişkinin her iki tarafındaki çokluk ifadeleri $\left(0 .{ }^{*}\right)$ tanımlanmıştır. Değerleme verileri ve genel özellikleri hakkında yapılan anket çalışmasına göre, toplu değerlemede uygulamada karşılaşılacak farklı durumlar düşünülerek, sahada uzmanın müdahale şansı olmayacak şekilde değeri etkileyen tüm faktörler belirlenmiştir. Niteliklerin birçoğu sayısal niteliklerdir ancak sayısal olmayan birçok niteliğin veri tipinin de tanımlanması gerekmektedir. Bu sınıfın veya ilişkili olunan diğer sınıfların nitelikleri kullanılarak hesapla elde edilebilecek nitelikler (bina yaşı, inşaat maliyeti, vb.) ise yordam olarak tanımlanmıştır. İşyeri sınıfında da bina sınıfina benzer şekilde işyerlerine özgü nitelikler ve yordamlar tanımlanmıştır. Bu sınıfların diğer paketlerdeki sınıflarla olan ilişkileri (TapuKadastroBilgileri::Tapu vb.) de tanımlanmıştır (Şekil 8).

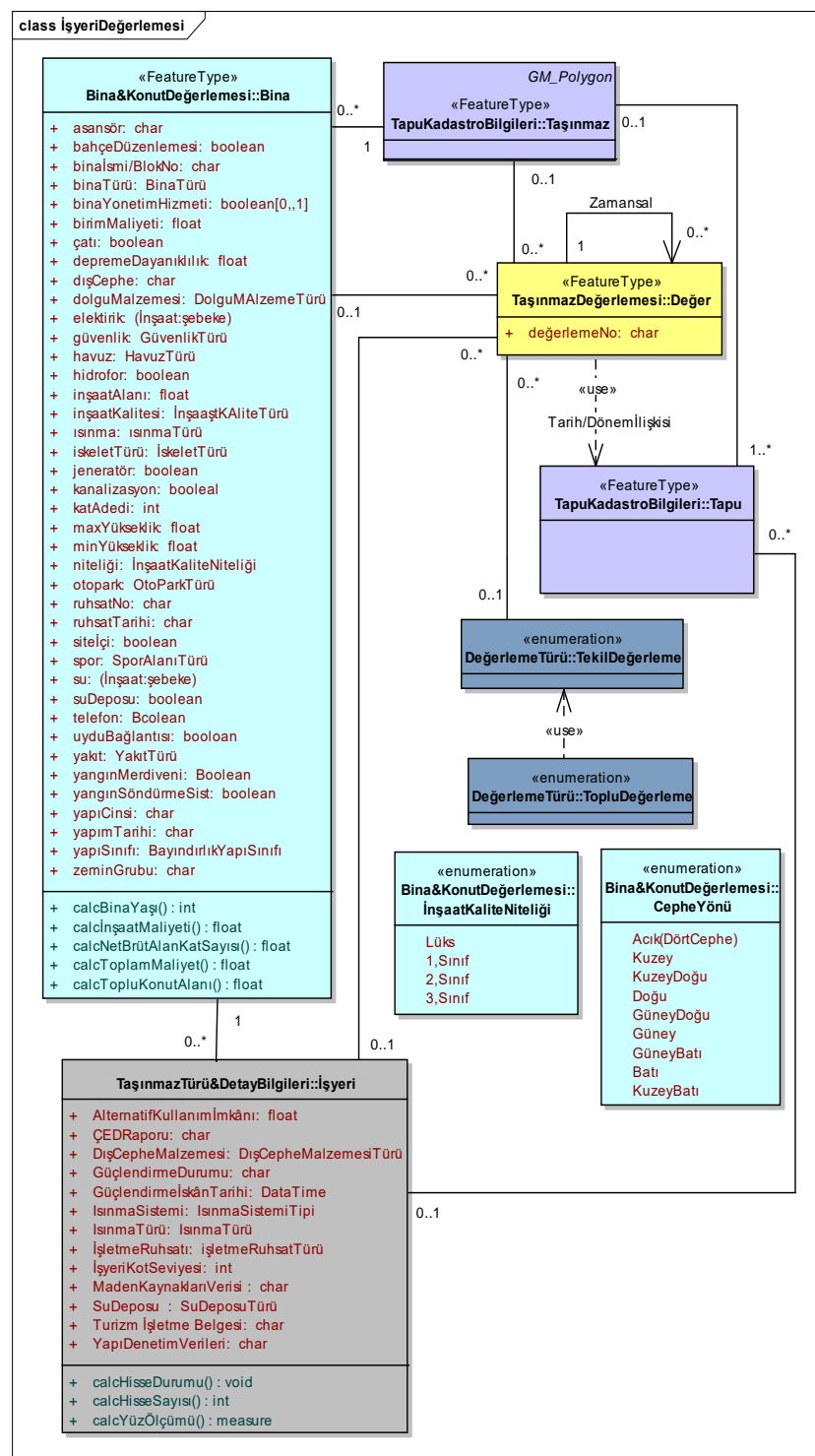

Şekil 8. İşyeri değerlemesi paketi içeriği.

\subsection{Taşınmaz Türü Detay Bilgileri Paketi}

Taşınmaz Türü Detay Bilgileri Paketinde yer alan her bir taşınmaz türü ayrı ayrı sınıflarla temsil edilmiştir. Sınıfların öznitelik bilgileri ait olduğu sınıfın detay bilgilerini içerecek şekilde oluşturulmuştur. Ancak, bütün sınıflarda ortak bulunmas1 gereken adres bilgileri (PaftaNo, AdaNo, ParselNo, İli, İlçesi... vb.) ile BinadakiKatSayısı, BinanınYapımYılı, ÇatıSistemi ve GüçlendirmeDurumu gibi bazı öznitelik bilgileri ortak kullanım zorunluğundan dolayı farklı sınıflarda da gösterilmiş ve aralarındaki ilişkiler tanımlanmıştır (Şekil 9). Bu sınıfların nitelikleri kullanılarak hesapla elde edilebilecek değerler (arazi eğimi, hisse sayısı, yüzölçümü vb.) ise yordam olarak tanımlanmıştır. 


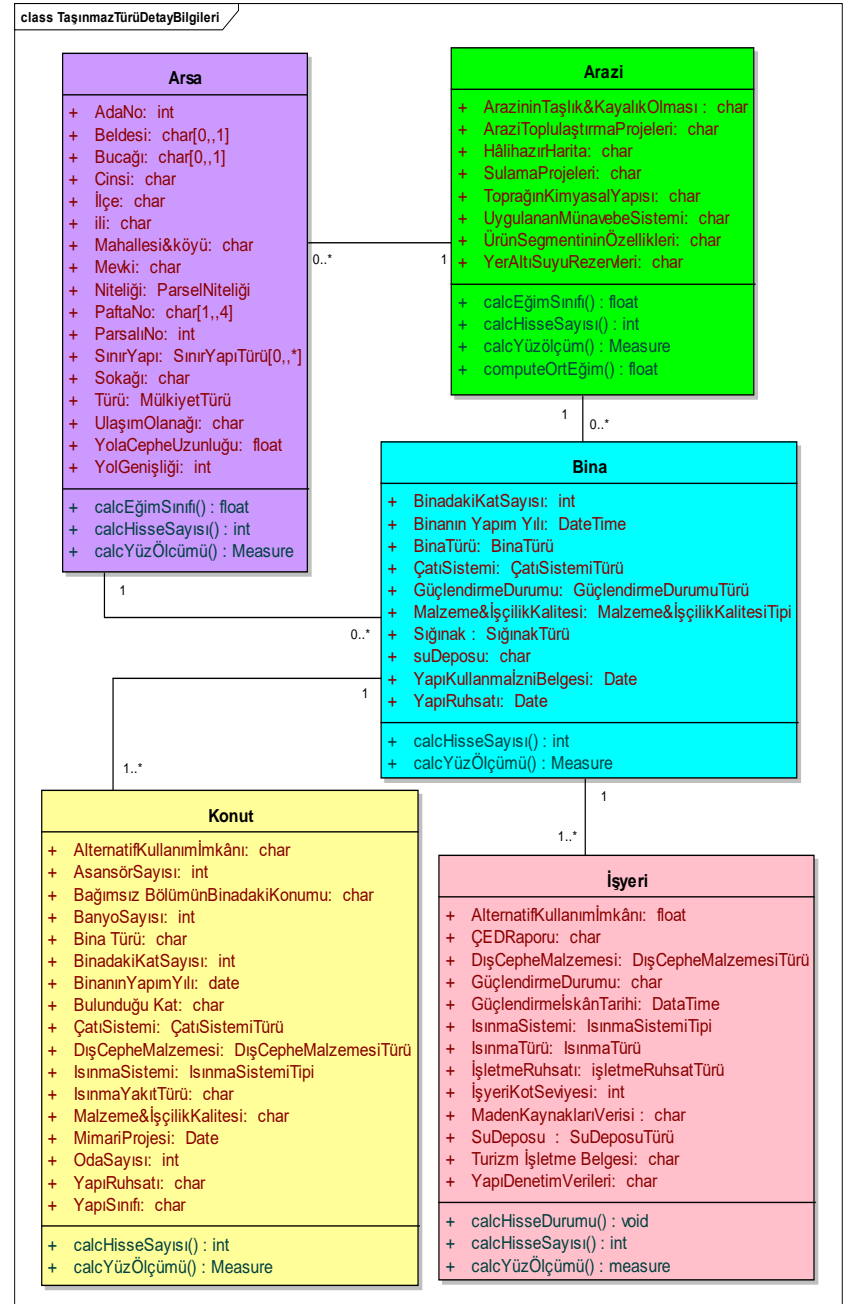

Şekil 9. Taşınmaz türü detay bilgileri paketi içeriği.

\subsection{Emsal Satışlar Paketi}

Toplu ve tekil değerlemeler sırasında aynı taşınmaz için tekrarlı değerleme işlemlerinden kaçınmak ve karşılaştırma yöntemiyle değerleme yaparken emsal değer bilgisine kolaylıkla ulaşabilmek için "değerlemesi yapılmış taşınmazlar veritabanı" da oluşturulmalıdır. Günümüzde bunun birkaç örneğini, bazı kamu ve özel sektör kuruluşlarının kendi bünyelerinde oluşturdukları kü̧̧ük çaplı veritabanı örneklerinde görmek mümkündür. Ancak bunlar şahsi veya kurum bazında kalmıştır ve sınırlı bölgelerde geçerlidir. Burada asıl sorun, bu veritabanını oluşturacak piyasadaki gerçek alım satım fiyatlarına ulaşamamaktır. Bunun için bir öneri olarak Tapu Müdürlüklerinde ABD'dekine benzer bir şekilde alım-satım harçları düşük tutulması düşünülebilir. Bu şekilde hem doğru olmayan beyan ihtimali azaltılmış olur ve hem de bu alandaki vergi gelirleri arttırılabilir. Bu sistemi hayata geçirebilmek adına gerçek satış fiyatı beyan etmeyenlere ağır para cezaları uygulanmalıdır.

Taşınmaz değerleri anlık değişebildiği için değerlemede kullanılacak tüm veriler sürekli güncellenmelidir. Değerlemede kullanılması gereken emsal satış verileri, UML tabanlı veri modelindeki EmsalSatışlar isimli veri paketi içerisinde oluşturulmuştur (Şekil 10). Paket içerisinde kamu kuruluşları tarafindan yapılan tüm özelleştirme, satış, kiralama ve kamulaştırma verileri ile piyasada yapılan normal alım-satım değeri sınıfları oluşturulmuş ve değerlemeyle ilgili (değer, tarih, numara vb.) olması gereken diğer bilgiler de ilgili sınıflarda öznitelik bilgisi olarak gösterilmiştir. Toplu değerleme yönteminin en önemli aşamalarından olan analiz ve model kurma çalışmalarının gerçekleştirilebilmesi için gerekli olan emsal taşınmaz verileri bu paket içerisinden alınması öngörülmüştür (Şekil 10). Verilerin güncelliğini sağlamak amacıyla aynı taşınmaza ait daha önceki değer bilgilerine erişim, Değer sınıfının kendi içerisinde tanımlı <<zamansal >> ilişkisi ile sağlanacaktır. $\mathrm{Bu}$ durum UML diyagramlarında gösterilmiştir. Ayrıca, değerlemede kullanılan taşınmaz karakteristikleri veritabanının oluşturulması adına, bir kısmı yüz yüze olmak üzere değerleme uzmanlarıyla yapılan anketler sonucunda, her taşınmaz türü için ayrı ayrı oluşturulan veri tablolarındaki bilgilerin, veri paketleri içerisinde oluşturulan sınıfların öznitelik bilgileri olarak kullanılması gerekmektedir.

ABD'dekine benzer bir şekilde emlakçılar, brokerlar (alıcı ve satıcının bir araya gelmesini kolaylaştırarak alışverişi hızlandıran kişiler), sisteme üye değerlemeciler $v b$. de veritabanına bilgi girebilmeli, sorgulama yapabilmelidir. Öncelikle emlakçılar, brokerlar ve değerlemeciler arasında bir platform oluşturulmalı ve bilgi paylaşımı yaygınlaştırılmalıdır.

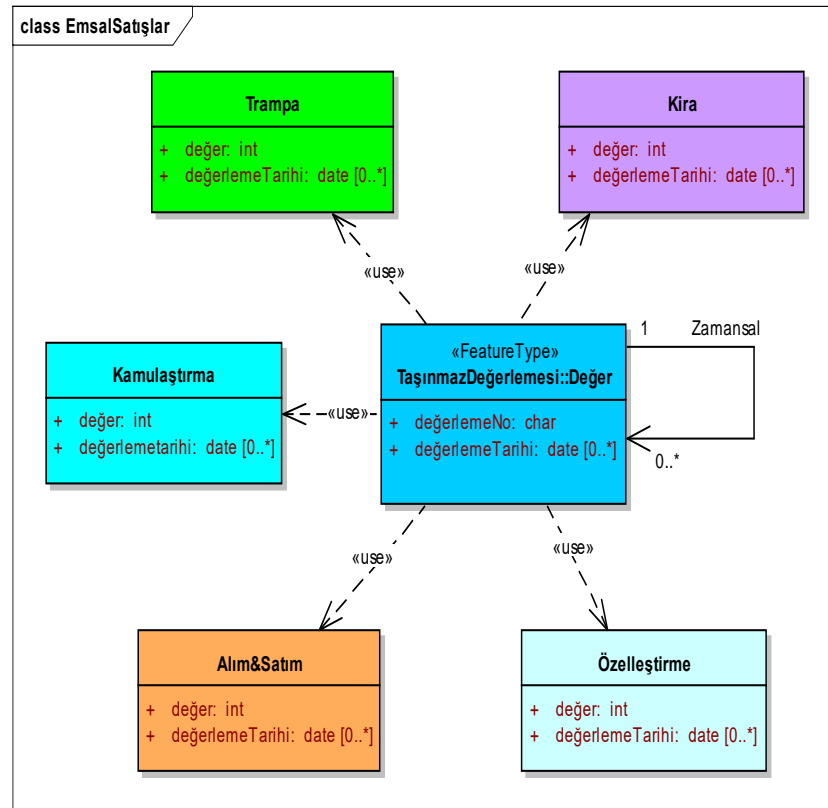

Şekil 10. Emsal satışlar veri paketi içeriği.

Emsal Satışlar veritabanında zamansal veri yönetimi sistemi oluşturulmalıdır. Ayrıca veri yönetimi faaliyetleri çok geniş kapsamlı olacağından, kullanılan verilerin sınırlandırılması gerekir. Değeri etkileyebilecek tüm ekonomik ve çevresel faktörler analize dâhil edilebilmelidir. 


\section{SONUÇ VE ÖNERILER}

Model çerçevesinde değerlemede kullanılması gereken verilerin temel özellikleri, taşınmaz değerine olan etkileri, birbiriyle olan ilişkileri, taşınmaz karakteristikleri ve emsal satışları kapayan bir temel veritabanı oluşturulması için yapılması gerekenler, UML sınıf diyagramlarıyla görsel olarak oluşturulmaya çalışılmıştır. Ancak bu ve benzeri işlemlerin tüm ülke genelinde belli standart ve kalitede yürütülebilmesi için çalışma kapsamında önerilen, genel hatlarıyla içeriği oluşturulan ve değerleme faaliyetlerinin tek bir yasayla yönetilmesini hedefleyen Taşınmaz Değerleme Kanunu (TDK) gibi bir kanunun olmasına ihtiyaç vardır. $\mathrm{Bu}$ kanunun oluşturulması sırasında, burada sunulan UML tabanlı veri modeli tasarımının yol gösterici olacağı öngörülmektedir.

Taşınmaz değerleme sistemin hayata geçirilmesi ve sürdürülebilirliğinin sağlanması için değerlemeyle ilgili doğru ve güncel verilerin sahadan toplanması ve bir veritabanında tutulması, bütün bu işlemler için de bir uygulama yönetmeliği çıkarılması gerekmektedir.

Değerleme sahasında gelişmiş diğer ülkelerde olduğu gibi, kullanılması gereken veriler için sayısal veri tabanları oluşturulmalı, uzmanlar belli bir ücret karşılığında bu verilere ulaşabilmelidir. Böylece rapor hazırlama sırasında oluşabilecek gecikmeler ve hatalar en aza indirilebilecektir. Geliştirilen UML veri modeli paketinin içerikleri bu önerilen veritabanının statik yapısının (veri tablolarının yapılarının değişmemesi durumu) ortaya konulabilmesi esasına göre oluşturulmuştur. Modelde statik veri tabanı kullanılması sayesinde entegre bir tasarım elde edilmiştir. Bu veritabanı statik olmakla birlikte değerleme sisteminde olabilecek değişiklikler karşısında güncellenebilir olmalıdır.

\section{BİLGILENDİRME}

$\mathrm{Bu}$ çalışma, Dr. Nuri ERDEM'in 2016 yılında Erciyes Üniversitesi, FBE, Harita Müh. Anabilim Dalında tamamlamış olduğu "Türkiye İçin Bir Taşınmaz Değerleme Sistemi Yaklaşımı" isimli doktora tezinden üretilmişstir.

\section{TEŞEKKÜR}

Çok yoğun çalışmaları arasında zamanlarını ayırarak bu çalışmanın gerçekleştirilmesine katkı sağlayan, çok kıymetli görüş ve tecrübelerini benimle paylaşan, kamu ve özel sektör taşınmaz değerleme uzmanlarına teşekkür ederim.

\section{KAYNAKÇA}

[1]. HKMO, Sempozyum Bildiriler Kitab1, Arazi
Yönetiminde Taşınmaz Değerleme ve Kadastro Sempozyumu, ATO Uluslararas1 Kongre ve Sergi Saray1, HKMO\&TKGM, 22-23 Mayıs, Ankara, 240 s., 2012.

[2]. Çete, M., "Türkiye İçin Bir Arazi İdare Sistemi Yaklaşımı", Karadeniz Teknik Üniversitesi, Fen Bilimleri Enstitüsü, Doktora Tezi, Trabzon, 243 s., 2008.

[3]. Köktürk, E., Köktürk, E., "Taşınmaz Değerlemesi, Taşınmaz Hukuku - İmar Hukuku - Değerleme Yöntemleri”, Seçkin Yayıncılık, 2. Baskı, Ankara, ISBN 978-975-02-312, 1304 s., 2015.

[4]. ÇŞB, Türkiye Ulusal Coğrafi Bilgi Sistemleri Standartlarının Belirlenmesi Projesi: TUCBS, BI Bina Veri Teması Uygulama Şeması, ÇŞB, CBSGM, 2012.

[5]. Yomralığlu, T., "A Nominal Asset Value-Based Approach for Land Readjustment and Its implementation Using Geographical Information Systems", Doktora Tezi, Newcastle Üniversitesi, UK, 1993.

[6]. Nişanc1, R., "CBS ile Nominal Değerleme Yöntemine Dayalı Piksel Tabanlı Kentsel Taşınmaz Değer Haritalarının Üretilmesi”, Karadeniz Teknik Üniversitesi, Fen Bilimleri Enstitüsü, Doktora Tezi, Trabzon, 230 s., 2005.

[7]. Ertaş, M., "Kırsal Alanlarda Taşınmaz Değerlemesi", Ders Notları, Selçuk Üniversitesi, Teknik Bilimler MYO, Konya, 2014.

[8]. Düzgün, H. Ş., “Coğrafi Bilgi Sistemlerine Giriş”, Ünite 2-Veri Girişi, http://www.acikders.org.tr, 2010. (E.T.: Kasım, 23, 2015).

[9]. Aliefendioğlu, Y., “Türkiye'de Koruma Alanlarındaki Taşınmazların Kullanımı ve Koruma Statülerinin Taşınmaz Piyasaları ve Değerlerine Etkileri: Muğla İli Örneği”, Ankara Üniversitesi, Fen Bilimleri Enstitüsü, Doktora Tezi, Ankara, 774 s., 2011.

[10]. Page-Jones M., "Fundamentals of Object-Oriented Design in UML", Addison-Wesley, Dorset House Publishing, New York, ISBN: 020169946X, 2002.

[11]. İnan, H., "Arazi İdare Sisteminin Tarım Bileşeni Olarak Konumsal Veri Modeli Geliştirilmesi”, Karadeniz Teknik Üniversitesi, Fen Bilimleri Enstitüsü, Doktora Tezi, Trabzon, 199 s., 2010.

[12]. Çağdaş, V., "Türkiye İçin Bir Emlak Vergi Sistemi Tasarım Modeli Önerisi”, Y Yldız Teknik Üniversitesi, Fen Bilimleri Enstitüsü, Doktora Tezi, İstanbul, 226 s., 2007.

[13]. Bostancı, B., İnan, H. İ., Çete, M., Geymen, A., Erdem N., "UML Tabanlı Taşınmaz Değerleme Modeli Tasarımı: Konut Değerleme Örneği”, II. Arazi Yönetimi Çalıştayı, 2122 Mayıs, İTÜ, İstanbul, 2012.

[14]. TKGM, TKMP-Gayrimenkul Değerleme Bileşeni Pilot Uygulama Taslak Tamamlanma Raporu, TKGM Kadastro Dairesi Başkanlığı, 182 sayfa, Ankara, 2014.

[15]. http://www.aartibirgd.com/tarim.html, (E.T.: Kasım, $17,2015)$. 